
\title{
R Reserach S Surare \\ The Mediating Role of E-Health Literacy in the Relationship Between Coronavirus Awareness and Hope in the Covid-19
}

Aykut Gunlu ( $\nabla$ agunlu@pau.edu.tr)

Pamukkale University: Pamukkale Universitesi https://orcid.org/0000-0002-6617-2871

\section{Research Article}

Keywords: Covid-19, pandemic, coronavirus awareness, e-health literacy, dispositional hope

Posted Date: May 18th, 2021

DOI: https://doi.org/10.21203/rs.3.rs-427296/v1

License: (c) (i) This work is licensed under a Creative Commons Attribution 4.0 International License.

Read Full License 


\section{Abstract}

This research aims to determine the mediating role of e-health literacy levels on the relationship between awareness of coronavirus precautions for Covid-19 and dispositional hope during the Covid-19 era. The current research is based on sequential explanatory design. The quantitative data in this research were collected online Google form, and the qualitative data were collected using the online interview technique. Participants from whom qualitative data were obtained were determined using the analog sampling method, one of the criterion sampling method. Participants from whom the quantitative data of the study were obtained were determined using the snowball sampling method, one of the purposeful sampling methods. As a result of testing the structural equation model, it has been determined that e-health literacy has a full mediating role between awareness of koronavirus and dispositional hope. In addition, in the study, it was observed that people who had Covid-19 increased their awareness of Covid-19 before and after the disease. It has been determined that people pay more attention to the precautions that should be taken for the transmission of the disease, especially after the disease. As a result, it can be said that the necessity of raising the awareness of individuals and giving priority to increasing the level of e-health literacy has emerged.

\section{Introduction}

The virüs, which emerged as a new coronavirüs in Wuhan, China in 2019, called Covid-19 (coronavirus) has changed our habits of life. The virus has spread to a large part of the world in a short time and has become inevitable. As a result, on 11 March 2020, the World Health Organization (WHO) officially declared the Covid-19 outbreak as a pandemic due to the global spread and severity of the disease. The coronavirus pandemic is defined as the biggest natural disaster experienced in recent years that has affected societies in the world in many ways, and the numbers of coronavirus clearly show this. In the world, it is stated that the number of cases exceeds 96 million, while the number of deaths exceeds 2 million (World Health Organization, 2020; Ministry of Health, 2020).

Outbreaks in history have affected states positively or negatively in many areas from agriculture to education, health to politics. While outbreaks cause the effect of some important values to weaken, some values are effective in coming to the fore. For example, the Spanish flu has made realization of the value of protecting public health. The Covid-19 pandemic has shown that the development levels of countries may not always be sufficient alone. Although being a developed country alone is not enough, the importance of development in this process is clearly seen. Turkey has criticized aspects of the pandemic period, though it is stated that a successful policy in general (Turkish Medical Association, 2020). Covid19 has highlighted the perception of states' "my own society, my own nation" rather than globalism. Covid-19 has also increased the importance of states' struggle for total mobilization and cooperation (Aydınlı, 2020). States should cancel international flights for a while to keep the epidemic under control in order to protect the health of both their own nation and other nations, keep citizens coming from abroad under a 14-day quarantine, implement curfews in the country, and switch to flexible working hours in the public and private sectors. While these measures taken by the states are effective in reducing human 
mobility, on the other hand, it is seen that they are effective in increasing some psychological problems in people (Unutulmaz, 2020).

Increasing cases and mortality rates are seen to play an important role in the change and reorganization of people's behavior in the face of the pandemic. This new order, expressed by the Ministry of Health, has been conceptualized with the "new normal". It is seen that it is difficult for individuals to adapt to the new normal. Difficulties experienced in the process of adapting to the new normal can also negatively affect the coping skills of individuals (Gonzalez-Sanguino et al., 2020; Li, et al., 2020; Lu et al., 2020, Oral \& Gunlu, 2020; Van Bavel et al., 2020). In addition, being late in the development of an effective vaccine against the pandemic, misinformation about the vaccine and the pandemic can also make it difficult to adapt to this new normal. However, the uncertainty experienced by individuals; it can be effective in increasing fear, hopelessness, unhappiness and despair (Xiao, Zhang, Kong, Li, \& Yang, 2020).

It has been observed that the anxiety levels of the people living in the environment where the individuals with the disease are located are higher than the people living in the environment without the disease (Çölgeçen \& Çölgeçen, 2020). Although the individual is not infected, it has been determined that contact quarantine has a negative effect on the individual's mental health (Erdoğdu, Koçoğlu, \& Sevim, 2020). Both the uncertainty of the effect of the precautions that can be taken against the pandemic and the fact that the individuals see the circle of viruses narrowing with each passing day, their life satisfaction decreases, it is stated that levels of hopelessness for the future increase (Dugas, Freeston, \& Ladouceur, 2020, Rajkumar, 2020). For this reason, it is important for individuals to access correct information in these periods to protect their mental health.

It is known that individuals use different strategies to deal with their problems. Some of them follow the news about Covid-19 to get information from news sources, some use the cognitive coping strategy, and some of others use the secular coping strategy (Asıcı, 2020; Illbasmış, Aksoy, Cihanyurdu, Ünver, \& Arman, 2020; Kaplan, Sevinç \& İşbilen, 2020). Another way individuals to dealing with the epidemic is to collect information about the epidemic with the help of smartphones. Current information about the pandemic are instantly delivered to the masses via smartphones or social networks such as Instagram and Twitter. During the pandemic period, a research was carried out on the Twitter post of Health Minister Fahrettin Koca. In the research, it was observed that there was a serious increase in the Twitter posts of Minister Koca before the pandemic and during the pandemic period. In addition, it is observed that the number of followers has increased five times during the epidemic period compared to the pre-pandemic and exceeded five million. This situation can be considered as people seeing the Minister of Health as a reliable source of information.

It is known that not only prevention of disease transmission but also prevention of misinformation flow is important in protecting public health (Kickbusch, 2001). In the early stages of the pandemic, one of the important issues that scientists fight with the pandemic is infodemia. Infodemia means misinformation or information pollution (Okyay, 2016). The first step in combating infodemia is increasing the level of health literacy. Health literacy was first defined by Simonds in 1974. WHO (2013), on the other hand, 
defined health literacy as the ability of the individual to reach the right information in order to maintain his/her basic health and use the information obtained for the maintenance of his/her health. Parvanta (2011) defined health literacy as the ability not only to understand health or disease related information, but also to understand and use complex information about health or disease, prescriptions, and drug use descriptions. The Ministry of Health defined the definition of e-health as conveying accurate and effective information about health to people in the shortest time possible with the advantage of technology's information transfer (Özer, Şantaş, \& Budak, 2012). It has been observed that, thanks to the widespread use of the internet in recent years, people use the internet to obtain information about the disease and to find the most reliable health institutions or doctors (Birru et al., 2004; Spadaro, 2003). In addition, various internet program providers offer their users the opportunity to create new content. This situation makes it difficult to control the content of the information on the internet (Bertot, 2012). In addition, it is stated that individuals' insufficient knowledge about health literacy causes them to be insufficient to decide which information on the internet is accurate and reliable (Skinner, Biscope, Poland, \& Goldberg, 2003). It is stated that digital generations, especially individuals who use the internet extensively, are insufficient to reach reliable information sources and to understand them (Coşkun \& Bebiş, 2020).

It is stated that health literacy is effective in preventing and treating diseases, especially in the timely and correct use of medicines, and in keeping track of doctor's appointments. It is one of the warnings made by experts that health services should not be unnecessarily occupied, especially during the pandemic period. (Aslantekin \& Yumrutaş, 2014; Eicher, Wieser \& Bruegger, 2009; Howard, Gazmararian \& Parker, 2005; Paakkari \& Okan, 2020; Yılmaz \& Tiraki, 2016). For example, in the study conducted by Berkman (2011), it was found that low health literacy increased the rate of inpatient treatment in hospitals, caused more occupation of emergency services, and caused the messages conveyed about health to be misunderstood. A similar result was obtained in the literature by Gray, Klein, Noyce, Sesselberg, and Cantrill (2005), and it was determined that individuals had difficulties in using and understanding e-health information. In addition, individuals with a high level of health literacy are more conscious of wrong and distorted media information. Such individuals accept the information presented to them after the logic filter and research (Sezgin, 2013). As a matter of fact, it is stated that this process includes the qualities of health literacy suggested by Nutbeam and can reduce the risk of disease transmission thanks to the awareness that can be gained to individuals (Sorensen et al., 2012).

The fact that the Covid-19 pandemic lasts longer than expected increases the importance of compliance with the prevention measures put in place by the states to prevent the pandemic. Adherence to the measures is seen to be related to the high awareness of the public about the importance of the measures and the conscious health literacy. It is stated that the high level of awareness of individuals and whether the individual is hopeful for the future also affects the level of compliance with the measures (Hamermesh, 2020). Future expectation, happiness in life, the meaning attributed to life, and the individual's feeling of good and healthy oneself are important factors affecting the mental health of the individual (Chen et al., 2017). Therefore, individuals with high hopes for the future are able to take a stronger attitude towards the difficult living conditions they encounter and are more successful than other 
individuals in finding solutions to problems by looking at the positive aspects of the events (Avşaroğlu \& Koç, 2019).

In the pandemic period, the priority thing to do is to protect individuals from contagious diseases. In other words, it is to protect the physical health of individuals. It is important to take the necessary measures for this (Oral, \& Gunlu, 2021). However, these measures (stay at home, social isolation, etc.) may not only protect the physical health of the individual, but also negatively affect the mental health of the individual. Furthermore, it is observed that the negative effects of these measures and measures on people are not at the same level. For example, while it affects some individuals excessively, some individuals rarely negatively; on some individuals it appears to have no negative effects whatsoever. Therefore, the fact that it has different effects on individuals suggests that there may be mediating variables that may cause individuals to be negatively affected. Therefore, the present study is thought to be important in terms of contributing to the determination of these mediator variables that affect the mental health of the individual.

One of the aims of this research is to determined the mediating effect of e-health literacy levels on the relationship between individuals' awareness of Covid-19 and dispositional hope in the process of Covid19 pandemic. Another aims of this research is to determine the experience of patients with Covid-19 disease. In the early days of the pandemic, it was observed that scientists directed the public towards more confusion and unhelpful practices rather than gaining awareness of the disease due to the fact that Covid-19 is a new disease and the lack of evidence-based information (Bulut, 2020). In this way, it is thought that is important to reach accurate and reliable sources in a conscious way in terms of understanding the severity of the disease and realizing the importance of prevention measures. The current study is important in terms of its contribution to overcoming this deficiency in the field.

\section{Method}

\subsection{Research Design}

The current research is based on sequential explanatory design, one of the mixed design research methods in which qualitative and quantitative research methods are used together. Combining the results obtained from the qualitative and quantitative data, the mixed method research provides a better understanding of the subject. Sequential explanatory design is based on the principle of obtaining quantitative data, and then investigating in depth the unexpected results from the quantitative data (Creswell, 2003; Johnson \& Onwuegbuzie, 2004). The qualitative part of the research was carried out based on the case study, one of the qualitative research designs. Case study is a method that aims to define, explain and predict in depth the relationships between the facts by revealing the uncertain points in an event or situation (Gay, Mills, \& Airasian, 2009). The case study is an important research design as it provides to handle the phenomenon in real life $(Y i n, 2014)$. For this reason, the purpose of a case study is not to reach too many people but to examine the situation in depth (Gilham, 2000).

\subsection{Study Group}


Qualitative data were collected from individuals who were selected using the benchmark sampling method using analog sampling method. In this context, qualitative data were obtained from a total of five people in three families with Covid-19 disease. The quantitative data of the study were collected from people selected by snowball sampling method, one of the purposeful sampling methods. For this purpose, a total of 301 people were reached and the scales were filled in via Google form. 145 of the participants are female (48.2\%), 156 of them are male (51.8\%). It was determined that the age range of the participants were between $15-40$, and the average age was 21.44 .

\subsection{Process}

Since the current research is based on a mixed design research model, "voluntary participation consent" was obtained from the participants in both data collection methods. The purpose of the study was conveyed to the participants and it was stated that they could quit the study whenever they wanted. The qualitative data obtained in the research were obtained as a result of online video interviews conducted by the researcher with the participants. Each interview lasted 15-20 minutes on average. The quantitative data obtained in the research were obtained through the Google online form. T Online data collection technique has been used because face-to-face interviews due to the pandemic pose health risks. There are eight basic questions in the qualitative data form. Content analysis method was used in the analysis of the qualitative data obtained. Content analysis is the method in which the relationships between the data are determined by collecting the qualitative data obtained in certain themes, categories and codes (Yıldırım \& Şimşek, 2011). The analysis of the quantitative data of the research was carried out through SPSS package program and AMOS programs.

\subsection{Data Collection Tools}

The interview technique is a frequently used qualitative data collection method, since it provides a large data flow to the researcher in obtaining qualitative data. During the data collection phase, the semistructured interview form was delivered to the person to be interviewed online. Subsequently, the data was obtained by asking questions through the video call made with the smartphone. Descriptive and evaluative question types were used while creating the questions in the interview technique. For example, "How did you feel to be known as a Covid-19 patient?", How was your awareness of life after The Covid19 disease?" questions are examples of questions on the form. In order to obtain the quantitative data of the study were used "E-Health Literacy Scale", "Coronavirus (Covid-19) Awareness Scale" and "Dispositional Hope Scale".

\subsubsection{Personal information form}

The personal information form of the research was created by the researcher himself and consists of questions to determine the demographic variables (age, gender) of the participants.

\subsubsection{E-Health Literacy Scale (eHEALS)}


Norman and Skinner (2006) developed the E-health Literacy Scale, and it was adapted to Turkish by Tamer-Gencer (2017). It has been developed to measure the knowledge and skills of people in accessing e-health information. The scale is scored between 8-item, 5-point Likert type, between I strongly disagree (1) and I completely agree (5). The lowest score on the scale can be 8 , and the highest score is 40 . High scores from the scale indicate that individuals have high e-health knowledge and skills. It was determined that the internal consistency of the scale was 0.86 and the Cronbach Alpha coefficient was .92.

\subsubsection{Coronavirus (Covid-19) Awareness Scale}

The Coronavirus Awareness Scale was developed by Bilgin (2020). The scale consists of 17 items and 3 sub-dimensions (awareness of contamination measures-9 items, awareness of following current developments-4 items, awareness of hygiene measures-4 items). The scale is scored between never (1) and always (5) in 5-point Likert type. Each sub-factor is evaluated separately. A high score that can be obtained from sub-factors indicates that the level of awareness for that factor is high. The Cronbach's Alpha internal consistency coefficient of the scale was 0.93 for the first factor, 0.87 for the second factor and 0.82 for the third factor.

\subsubsection{Dispositional Hope Scale}

Dispositional Hope Scale Snyder et al. (1991), adapted to Turkish by Tarhan and Bacanlı (2015), and consists of 12 items and 2 sub-dimensions (Alternative Ways Thinking-4 items, Actuating Thinking-4 items) (4 items are fillers). The scale is scored in 8-point Likert type (absolutely false-1, mostly false-2, quite wrong-3, slightly wrong- 4 , slightly true- 5 , quite true- 6 , mostly true-7, absolutely true-8). The total score is obtained from the scale and the scores that can be obtained vary between 8 and 64 . High scores from the scale indicate that the individual has a high level of hope. The Cronbach Alpha internal consistency coefficient of the scale was found to be 0.86 .

\subsection{Ethical rules in Quantitative and Qualitative Research}

Before starting the research, permission was obtained from the Ministry of Health and the study started in accordance with the permission numbered 2020-12-20T02_43_07. While obtaining data from the participants, the subject and purpose of the study were clearly conveyed, and it was assured that the information obtained would only be used within the scope of the academic study. And then "voluntary participation consent" was obtained from the participants in both data collection methods. In addition, a code is assigned to keep the identity information of the participants confidential, especially when obtaining qualitative data (Miles \& Huberman, 2017). Therefore, in the analysis of qualitative data, participants were assigned a code (for example, the " $1 \mathrm{M}$ " code for the first participant and his gender ( $M=$ male, $F=$ female).

\subsection{Reliability and Credibility of the Study}

In qualitative research, the concepts of reliability and credibility are preferred over internal and external validity concepts (Yıldııım \& Şimşek, 2011). In order to ensure credibility in the current study, inspired by 
the studies on the epidemic in the literature, questions that enable data collection on all aspects of the subject are included in the research. One of the methods used to ensure the external validity of the research is to determine the similarity with the findings of previous completed studies (Shenton, 2004). In order to achieve this, the results of previous studies and the results obtained from the current research are discussed in detail, especially in the discussion section.

The way to increase the reliability of the study is to make expert (colleague) evaluation. This method is also called rater consistency (Creswell, 2013; Miles \& Huberman, 2017). In line with this purpose, decipherings were sent to two experts working in the field and their opinions on this issue were received. Common themes and codes were created by comparing the content analysis obtained as a result of the opinions received. In addition, to ensure the internal reliability of the study, the study should be reported objectively (Connelly, 2016). In order to achieve this, the data obtained were first deciphered, and then themes, categories and codings were created using the content analysis method. In addition, by giving examples from the expressions of the participants, the credibility of the relevant theme or codes was tried to be achieved.

\section{Results}

In this section, first of all, the analysis of quantitative data and the findings obtained are shared. Later, the results of the qualitative data were shared and examples of participant expressions related to the themes obtained were presented.

Relationships between the variables of the study were analyzed with the Pearson Correlation test. Relationship levels between variables, mean, standard deviation, skewness, kurtosis, Cronbach Alpha values of variables are given. Accordingly, the relationship between the variables of the study is showned in Table 1.

Table 1 Correlation values and descriptive statistics for the relationships between variables 


\begin{tabular}{|c|c|c|c|c|c|c|c|}
\hline & 1 & 2 & 3 & 4 & 5 & 6 & 7 \\
\hline 1- Contagion precaution awareness & 1 & $.40 * \star$ & $.49 * \star$ & $.12^{\star}$ & $.14^{\star}$ & $.12^{\star}$ & $.13^{\star}$ \\
\hline $\begin{array}{l}\text { 2- Awareness of follow current } \\
\text { developments }\end{array}$ & & 1 & $.41 * \star$ & $.17 \star \star$ & $.14^{\star}$ & $.13^{\star}$ & $.13^{\star}$ \\
\hline 3- Hygiene precaution awareness & & & 1 & $.16^{\star \star}$ & $.13^{*}$ & $.14^{*}$ & $.11^{\star}$ \\
\hline 4-E-Health Literacy parcel-1 & & & & 1 & $.75^{\star \star}$ & $.25^{\star \star}$ & $.19 * \star$ \\
\hline 5-E-Health Literacy parcel-2 & & & & & 1 & $.28^{\star \star}$ & $.22^{\star *}$ \\
\hline 6-Alternative Ways Thinking & & & & & & 1 & $.81^{* *}$ \\
\hline 7-Action Thinking & & & & & & & 1 \\
\hline Average & 40.01 & 15.74 & 15.02 & 14.21 & 14.77 & 24.97 & 24.10 \\
\hline Standard deviation & 5.07 & 4.3 & 3.67 & 4.11 & 3.76 & 4.97 & 5.03 \\
\hline Skewness & -1.83 & -.91 & -.90 & -.46 & -.44 & -.67 & -.52 \\
\hline Kurtosis & 1.79 & -.09 & .59 & -.31 & -.42 & .21 & -.23 \\
\hline Cronbach alpha & .85 & .87 & .77 & .92 & .87 & .74 & .76 \\
\hline
\end{tabular}

$\mathrm{N}=301,{ }^{*} p<0.01,{ }^{*} p<0.05$

Considering the descriptive statistics in Table 1, it is seen that the variables discussed in the study show a normal distribution. When the correlation values are examined, it is seen that there are significant relationships between both the sub-dimensions of the scales and between the sub-dimensions of one scale and the sub-dimensions of other scales. A positive significant relationship was found between contagion precaution awareness, awareness of following current developments $(r=.40, p<.01)$, hygiene precaution awareness $(r=.49, p<.01)$, e-health literacy parcel-1 $(r=.17, p<.05)$, e-health literacy parcel-2 $(r=.14, p<.05)$, alternative ways thinking $(r=.12, p<.05)$, action thinking $(r=.13, p<.05)$. Similarly a positive significant relationship was found between awareness of following current developments, $\mathrm{e}$ health literacy parcel-1 $(r=.17, p<.01)$, e-health literacy parcel-2 $(r=.14, p<.05)$, alternative ways thinking $(r=.13, p<.05)$, action thinking $(r=.13, p<.05)$. A positive significant relationship was found between hygiene precaution awareness, e-health literacy parcel-1 $(r=.16, p<.01)$, e-health literacy parcel-2 $(r=.13$, $p<.05)$, alternative ways thinking $(r=.14, \mathrm{p}<.05)$; action thinking $(r=.11, \mathrm{p}<.05)$. Furthermore analysis revealed significant positive relationship between e-health literacy parcel-1, e-health literacy parcel-2 ( $r=$ $.75, p<.01)$, alternative ways thinking $(r=.25, p<.01)$ and action thinking $(r=.19, p<.01)$. A positive significant relationship was found between e-health literacy parcel-2, alternative ways thinking $(r=.28, p$ $<.01)$ and action thinking $(r=.22, p<.01)$. Finally, a positive significant relationship $(r=.81, p<.01)$ was found between alternative ways thinking and action thinking. Cronbach's alpha reliability coefficients $(a=$ $.74, a=.76, a=.77, a=87$ and $a=.92)$ of scales and their sub-dimensions were found to be sufficient (Büyüköztürk, 2010). 


\subsection{Findings Regarding the Measurement Model and Testing the Model}

Considering the analysis results in Table 1, it was determined that the observed variables were significantly related to each other. Fit indices frequently used in testing the measurement model; Chisquare fit $\left(\chi^{2}\right)$ and the ratio of chi-square to degrees of freedom $\left(\chi^{2} / d f\right)$, Root Mean Square of Approximate Errors (RMSEA), Standardized Residual Means Square Root (SRMR), Good Fit Index (GFI), Normed fit Index (NFI), Comparative Fit Index (CFI), and Adjustment Goodness of fit Index (AGFI) (Bayram, 2016; Brown, 2006). Accordingly, before the analysis of moment equation model, the measurement model showing the relationships between observed variables and latent variables were tested and the values obtained were presented in Table 2 and Fig. 1. Considering the result obtained, it was seen that the fit values of the measurement model were at a good fit $\left(X^{2} / d f=1.68, p<.001, R M S E A=\right.$ $.05, S R M R=.02, \mathrm{GFI}=.98, \mathrm{CFI}=.99, \mathrm{AGFI}=.97)$. Variation of the obtained factor loads between .37 and 1.00 indicates that the observed variables represent the latent variables significantly.

Table 2 Measurement model fit indices

\begin{tabular}{|llll|}
\hline Measurement & Goog Fit Values & Curent Values & Comment \\
$X^{2} / \mathrm{df}$ & $\leq 3$ & 1.68 & İyi uyum \\
RMSEA & $\leq 0.05$ & 0.05 & İyi uyum \\
SRMR & $\leq 0.05$ & 0.02 & İyi uyum \\
GFI & $\geq 0.90$ & 0.99 & İyi uyum \\
CFI & $\geq 0.97$ & 0.99 & İyi uyum \\
AGFI & $\geq 0.90$ & 0.97 & İyi uyum \\
\hline
\end{tabular}

$N=301$

\subsection{Structural Equation Model for the Mediating Role of E-Health Literacy in the Relationship Between Coronavirus Awareness and Dispositional Hope}

Baron and Kenny (1986) stated that in order to test the mediating variable with the structural equation model, there should be a significant relationship between dependent (dispositional hope), independent (coronavirus awareness) and intermediary (e-health literacy) variables. Table 1 shows that there are significant relationships between variables. Considering the results in Table 1, it can be said that the results obtained are suitable for the analysis of the model (Şimşek, 2007).

According to the structural equation model analysis for the mediating effect of e-health literacy effect, the measurement model $\left(X^{2} / d f=1.68, p<.001, R M S E A=.05, S R M R=.02, G F I=.98, C F I=.99, A G F I=\right.$. 
97) was found to have good fit indices. The structural model for the analysis is presented in Fig. 2 and Fig. 3. According to the results of the analysis, it was determined that coronavirus awareness predicted ehealth literacy positively $(\beta=.26, p<.01)$, and e-health literacy positively predicted hope $(\beta=.29, p<.01)$. With the inclusion of e-health literacy as a mediator variable in the model, the power of coronavirus awareness to predict persistent hope $(\beta=.06, p<.05)$ decreased. It was seen that gender included in the analysis as the control variable did not have a significant effect on the mediator and dependent variable (Fig. 2). In other words, coronavirus awareness dispositional hope was significantly $(\beta=.06, p<.05)$ through e-health literacy. predicts.

\subsubsection{Bootstrapping process}

The significance of the direct and indirect effects of the variables in the model was examined with Bootstrap analysis, and the number of 1000 recommended in the literature was entered for the number of repeated sampling (Arbuckle, 2007). The coefficients belonging to the direct and indirect paths resulting from the Bootstrap analysis and the average effects in 95\% confidence intervals for these coefficients are presented in Table 3. Accordingly, it can be stated that all direct path coefficients are significant. It is seen that the indirect path coefficient, which enables the understanding of the intermediary role, is significant $(\beta=.06, p<.05, G . A .=.01, .14)$. In line with this result, it can be said that e-health literacy has a full mediating role between coronavirus awareness and dispositional hope.

Table 3 The Results of the Bootstrap Analysis Examining the Direct and Indirect Effects of the Structural Equation Model

\begin{tabular}{|c|c|c|c|c|}
\hline Model Patways & & & $\% 95 \mathrm{Cl}$ & \\
\hline Direct effect & & Coefficient & Bottoms & Top \\
\hline Covid-19 Aware. & $\rightarrow$ eHealth Literacy & $.26 * \star$ & .05 & .46 \\
\hline eHealth Literacy & $\Rightarrow$ Dispos. hope & $.29 * \star$ & .04 & .49 \\
\hline Covid-19 Aware. & $\Rightarrow$ Dispos. hope & $.14^{\star \star}$ & .01 & .33 \\
\hline \multicolumn{5}{|l|}{ Indirect effect } \\
\hline Covid-19 Aware. & $\Rightarrow$ eHealth L. $\Rightarrow$ Dispos. hope & $.06^{*}$ & .01 & .14 \\
\hline
\end{tabular}

\subsection{Awareness of People with Coronavirus Disease}

When the qualitative data of the study were evaluated, it was determined that the data were collected under the themes of thought, emotion, behavior, diagnosis of the disease, staying at home, habit, precaution / prevention and freedom. The themes and codes obtained are presented in Table 4.

Table 4 Perceptions of awareness of people with Covid-19 disease 


\begin{tabular}{|c|c|c|c|c|}
\hline \multirow{2}{*}{ Theme } & \multirow[t]{2}{*}{ Code } & \multicolumn{3}{|l|}{ Awareness } \\
\hline & & Pre-illness & Current of illness & Post-illness \\
\hline Thughts & Think & $\begin{array}{l}\text { Take it lightly, } \\
\text { don't believe }\end{array}$ & Understand seriousness & $\begin{array}{l}\text { Believe } \\
\text { seriousness }\end{array}$ \\
\hline \multirow[t]{3}{*}{ Emotioons } & \multirow[t]{2}{*}{ Anxiety } & \multirow{2}{*}{$\begin{array}{l}\text { Contagion } \\
\text { Anxiety }\end{array}$} & Dying Anxiety & \multirow{2}{*}{$\begin{array}{l}\text { Fear decreases } \\
\text { Happiness }\end{array}$} \\
\hline & & & $\begin{array}{l}\text { Sadness of separation from } \\
\text { loved ones }\end{array}$ & \\
\hline & Fear & $\begin{array}{l}\text { Fear due to } \\
\text { pregnancy }\end{array}$ & $\begin{array}{l}\text { Fear due to pregnancy } \\
\text { Increased }\end{array}$ & $\begin{array}{l}\text { Fear decreases } \\
\text { with recovery }\end{array}$ \\
\hline \multirow[t]{3}{*}{ Behaviors } & Mask & $\begin{array}{l}\text { Pay little } \\
\text { attention }\end{array}$ & Using a mask even indoors & $\begin{array}{l}\text { Do not wear a } \\
\text { double mask }\end{array}$ \\
\hline & Distance & Don't care much & $\begin{array}{l}\text { Don't keep the distance even } \\
\text { in the home }\end{array}$ & $\begin{array}{l}\text { Pay special } \\
\text { attention }\end{array}$ \\
\hline & Hygiene & $\begin{array}{l}\text { Don't pay } \\
\text { attention like } \\
\text { everyone else }\end{array}$ & Increased attention rate & $\begin{array}{l}\text { Pay much more } \\
\text { attention. }\end{array}$ \\
\hline \multirow[t]{2}{*}{$\begin{array}{l}\text { Health } \\
\text { care }\end{array}$} & Hospital & - & $\begin{array}{l}\text { Not wanting because of } \\
\text { pregnancy }\end{array}$ & - \\
\hline & \multicolumn{2}{|l|}{ Stigma } & \multicolumn{2}{|l|}{ Stigmatization } \\
\hline Attitude & $\begin{array}{l}\text { Family } \\
\text { attitude }\end{array}$ & Pay attention & $\begin{array}{l}\text { Everyone controlling each } \\
\text { other }\end{array}$ & $\begin{array}{l}\text { Much more } \\
\text { attention }\end{array}$ \\
\hline \multirow[t]{5}{*}{ Habits } & Protection & $\begin{array}{l}\text { Pay attention to } \\
\text { cleanliness }\end{array}$ & $\begin{array}{l}\text { Paying more attention to } \\
\text { cleanliness and social } \\
\text { distance }\end{array}$ & Be maximized \\
\hline & $\begin{array}{l}\text { Eating } \\
\text { habits }\end{array}$ & Normal & Pay more attention & $\begin{array}{l}\text { The importance of } \\
\text { a healthy diet }\end{array}$ \\
\hline & \multirow[t]{2}{*}{$\begin{array}{l}\text { Coping } \\
\text { Strategy }\end{array}$} & $\begin{array}{l}\text { Establishing } \\
\text { facetoface }\end{array}$ & Fully virtual communication & $\begin{array}{l}\text { Preferring virtual } \\
\text { communication }\end{array}$ \\
\hline & & Com. & & \\
\hline & $\begin{array}{l}\text { Social } \\
\text { Com. }\end{array}$ & Yes, sometimes & No & Absolutely no \\
\hline \multirow[t]{2}{*}{$\begin{array}{l}\text { Stay at } \\
\text { home }\end{array}$} & Constraint & $\begin{array}{l}\text { No need for } \\
\text { restrictions. }\end{array}$ & $\begin{array}{l}\text { It can be without freedom, } \\
\text { health first }\end{array}$ & $\begin{array}{l}\text { Health is more } \\
\text { important than } \\
\text { freedom }\end{array}$ \\
\hline & Izolated & Pay attention & $\begin{array}{l}\text { Being unable to leave the } \\
\text { house and feeling under } \\
\text { pressure }\end{array}$ & $\begin{array}{l}\text { The enjoyment of } \\
\text { freedom }\end{array}$ \\
\hline
\end{tabular}


The sub-category of the thought theme of the participants included thoughts such as underestimating the disease before the illness, and not believing in the illness, while these thoughts were changed during and after the illness, believing the illness and understanding the severity of the illness. Participant 3F "I didn't care much, I perceived it as a disease like flu, but when I got the disease, I saw that it was a very serious disease" and participant 5M "I thought there was no such disease. Thinking that they exaggerated the symptoms of the disease, I did not expect it to be so painful even if I caught the disease" is an example of the expressions that show the difference in thoughts between before and after the disease.

In the sub-category of the emotional theme, it was determined that the participants experienced the anxiety and fear of contamination with the illness before the illness. It was observed that they had death anxiety during the illness, sadness of staying away from their loved ones and fear of harming their loved ones. After the illness, it was observed that happiness was experienced as there was improvement, and the anxiety and fear of death decreased. Participant $1 \mathrm{~F}$ "I was afraid before the illness, but I was more afraid of the possibility of harm to my baby because I was pregnant when I got the disease, but my fear decreased after I recovered" and participant 2M "I had an intubated inpatient treatment at the hospital, I had an anxiety of separation from my loved ones and death, My anxiety disappeared after I got over the illness" are examples of the feelings of the participants.

It was determined that masks, distance and hygiene rules were included in the sub-category of the behavior theme of the participants. While the use of masks and distance rules are less followed before the illness, it is seen that there is a significant increase in awareness about observing the mask and distance rules during and after the illness. While a lot of attention was paid to hygiene rules before the disease, there was an increase in the case of hygiene during and after the disease. Participant $2 \mathrm{M}$ "The barber tradesman performs his job by standing very close to the customer. Therefore, before the illness, I was standing close to the customer, I could not obey the mask and distance rule very much. When customers weren't wearing it, I didn't feel the need to warn them either. However, after I recovered now, I started to use double masks while doing my work. I also warn those who try to enter the workplace without wearing a mask" indicates that there is an important awareness about masks, distance and hygiene.

It has been determined that the participants do not want to benefit from healthcare services because they are likely to be diagnosed with Covid-19. In addition, it was observed that the pregnant woman was more worried about getting sick at the hospital. Participant 3F stated that "I will be quarantined when my test is positive when I go to the hospital, and neighbors will see the healthcare teams that will come to my home and they will move away from me" stated that they do not want to apply to the health institutions.

It was determined that the individuals living in the family of the participants were not very sensitive to the epidemic before the disease, but if an individual in the family was sick, they were more careful and attentive to the epidemic during and after the disease, and they followed the rules more. It has been determined that everyone in the family pays more attention to distance and hygiene and warns each other about these issues. Participant 4F "My mother was also living with us when we were sick. The three 
of us were constantly checking each other during the quarantine. We were measuring each other's temperature and controlling our sense of smell and taste" can be given as an example of a concrete statement indicating the state of family members during fastness.

It was determined that there was no change in the protection of the participants from the pre-illness related to the epidemic. It was determined that the participants paid more attention to cleanliness and social distance during illness, their eating habits continued normally, and face-to-face communication was used in coping strategies. It has been determined that during the illness, more attention is paid to cleaning and protection methods, nutrition, and social communication is interrupted. After the disease, it was observed that the habits of the individual were deeply affected and the individual paid more attention. Participant 5M "We are still cleaning the door handles and the places we touch. I wear double masks when I go out. I was paying attention to my cleanliness and hygiene before and still continue in the same way" can be given as an example to explain the situation.

While the participants thought that there was no need for restriction before the illness, it was seen that the value of freedom was better understood during and after the illness, freedom is important, but freedom is also unimportant after health is not. Participant $3 F$ "I have understood that life is very simple, that health is very valuable, and that precautions should be taken so that life does not flow out of our hands and we do not leave our loved ones" can be given as an example to this situation.

\section{Discussion, Conclusion, Suggestions And Limitations}

\subsection{Discussion, Conclusion, Suggestions}

The present study has two main objectives. One of these aims is to examine the mediating effect of ehealth literacy on the relationship between individuals' awareness of coronavirus and their level of dispositional hope in the Covid-19 disease process. Another of the aims of the study is to determine the awareness of people who have had Covid-19 disease about their experience with Covid-19 disease. When the quantitative and qualitative data of the study are evaluated in line with these purposes, it is seen that the following results are obtained.

Looking at the results obtained from the data, it is determined that e-health literacy plays a full mediating role in the relationship between coronavirus awareness and dispisitional hope. In other words, it is seen that this relationship disappears when e-health literacy comes into play in the relationship between coronavirus awareness and dispisitional hope. In Karataş's (2020) study, it was determined that individuals' concerns about the future increased. It was determined that increased uncertainties about the future caused a decrease in the hope level of the individual. It has been determined that the decrease in the level of hope is more pessimistic, has more difficulty in setting goals, and has difficulties in solving the problems encountered (Green, Oades, \& Grant, 2006). In another study, a significant difference was observed between the hope levels of the participants in April 2020 and August 2020, and it was determined that as the quarantine period increased, the uncertainty regarding the epidemic continued (Cihanyurdu, İlbasmış, Aksoy, Ünver, \& Rodopman, 2020). 
Another important finding of the present study is that the awareness of individuals increases especially after the illness. It has been determined that warnings made to prevent transmission of the disease receive more attention after the disease has passed. It has also been demonstrated in studies that access to correct information for the public during epidemic periods is as important as protective measures to prevent the spread of the disease (Chen et al., 2020; Modi et al., 220; Quazi et al., 2020; Waadod et al., 2020). It has been determined that access to correct information not only preserves the hope level of individuals, but also increases their awareness of the disease. for the public are correctly informed the Ministry of Health when the action without losing history, in January 2020, the outbreak of the Scientific Committee and then immediately after a visit in Turkey established the ALO 184 MHCC Korona Hotline (Turan \& Çelikyay, 2020). In a study, it was determined that the public generally tried to obtain information through social media during the Covid-19 process. Although this situation enables the public to access information easily and in a short time, it is stated that the reliability of the information changes according to the news source or social network used by the individual. In the mentioned study, it was stated that a large part of the public saw the social network of Health Minister Fahrettin Koca as a reliable source (Çerçi, Canöz, \& Canöz, 2020). It is also emphasized in the literature that the public access to a reliable source of information in natural disasters such as pandemics is very effective in the correct action of the public and in the implementation of the measures that can be taken (Longstaff \& Yang, 2008; Tirkkonen \& Luoma-aho, 2011; Zhou et al., 2020). Studies in the literature reveal that a correct and healthy flow of information tends to perceive the perceived risk as high and to follow the measures that can be taken against this risk more (De Hoog, Stroebe, \& De Wit, 2007, Ruiter, Abraham, \& Kok, 2001). As a matter of fact, it has been determined in a study that high e-health literacy can prevent unnecessary occupation of health institutions, especially during epidemics (Goto, Ishikawa, Okuhara, \& Kiuchi, 2019).

It has been determined that there are significant changes in the pre-illness and post-illness perspective of the people with the disease. It was observed that the participants did not care about the disease before they got the disease and did not take the precautions and measures to prevent the transmission of the disease. While the negative feelings of the people who survived the disease increased, the awareness of the measures and measures to be taken against the disease increased. It was found that the participants experienced intense fears and anxieties about stigma with Covid-19, hospitalization, compulsory quarantine or harm to their baby due to pregnancy. In addition, it has been determined that individuals with the disease have anxiety of transmitting the disease to those around them. However, it has been determined that people who test positive for Covid-19 are more exposed to stigma and discrimination (Cyrus, Cornelia, \& Roger, 2020, Enli-Tuncay, Koyuncu, \& Özel, 2020). It is stated in the literature that there is a struggle to cope with stigma as much as the epidemic.

One way to deal with stigma is to increase e-health literacy and ensure that the right information is delivered to people (Ramaci, Barattucci, Ledda, \& Rapisarda, 2020). In the studies of MoghanibashiMansourieh (2020) and Tunca, Koyuncu and Özel (2020), it was determined that people with Covid-19 are in fear of transmitting the disease to their relatives. In the study conducted by Yang and $\mathrm{Ma}(2020)$ in China, it was observed that the well-being of individuals decreased by $74 \%$ and their unhappiness increased. In some other studies in the literature, it has been determined that individuals' levels of fear 
and anxiety increase during these periods (Bo et al., 2020). In a study conducted in China, it was determined that the condition of having relatives infected with Covid-19 increases the anxiety of individuals. However, in the literature, it has been determined that healthcare workers working at the front line, especially in the fight against the epidemic, have increased their anxiety and stress at first, but over time they have become strong in dealing with these negative situations (Sun et al., 2020). Özdin and Bayrak-Özdin (2020) determined that anxiety and health anxiety are seen at higher levels in women and people with chronic diseases in Turkish society. It is stated that this situation causes the individual to have a low level of hope for the future.

It was determined that there were serious differences in terms of taking into account the warnings made by scientists before and after the experience of the disease. It has been determined that there is an increase in positive behaviors such as paying more attention to cleanliness, gaining the habit of wearing masks, and obeying social distance rules when communicating with people face to face or when shopping. In the study conducted by Karataş (2020), it was determined that after Covid-19, an increase of $85-90 \%$ was observed in the cleaning, mask and hygiene behavior of individuals.

The current research has determined that individuals prefer virtual communication with people to cope with the negative effects of Covid-19. In the studies in the literature, it has been observed that people try to cope with the negativities of the epidemic, as well as with negative attitudes such as stigma and discrimination in the society (Oran \& Şenuzun, 2008; Terzioğlu, 2004; Wang, et al., 2020). It is emphasized that the information system should be healthy especially in the fight against the epidemic and active coping strategies should be taught (Çaykuş \& Çaykuş, 2020). It is stated that the first of these coping strategies include increasing the level of awareness and increasing the e-health literacy level of individuals (Polizzi et al., 2020). In addition, it is seen that being at home is an application area where problems are experienced in complying because it causes the individual to be deprived of his freedom. For this reason, it can be stated that realizing the importance of the measures that are difficult to comply with will be useful in preventing the epidemic. Especially, increasing awareness-based trainings for the correct and effective use of technology in the field of health can be effective in protecting society and public health.

\subsection{Limitations}

The study is important in terms of revealing the level of e-health literacy level of the individuals, especially in terms of epidemic periods. However, the study has some limitations. One of these limitations is that qualitative data are obtained from a limited sample. In addition, the data obtained are limited to the characteristics measured by the e-health literacy used, awareness of hygiene measures and dispositional hope scale. In future studies, researchers may be suggested to work with other variables that are thought to affect awareness of the epidemic. By applying various training programs aimed at increasing e-health literacy, its effectiveness can be tested.

\section{Declarations}


Funding We received no financial support for this investigation, authorship, and/or publication of this study.

Informed consent Informed consent was obtained from all individual participants included in the research.

Conflict of Interest The author no conflict of interest.

Ethical approval All procedures performed in studies involving human participants were in accordance with the ethical standards and with the 1964 Helsinki declaration and its later amendments or comparable ethical standards

\section{References}

Arbuckle, J. L. (2007). Amos 16.0 user's guide. Spring House, PA: Amos Development Corporation.

Aslantekin, F. \& Yumrutaş M. (2014). Health Literacy and Measurment. TAF Preventive Medicine Bulletin, 13(4), 327- 334. DOI:10.5455/pmb1-1364566995

Asıc E. (2020). Effects of The Pandemic on Mental Health. Journal of TYB Academy, 10(30):123-142. Retrieved from https://www.tybakademi.com/kitap/akademi30.pdf

Avşaroğlu, S., \& Koç, H. (2019). Yaşam doyumu ile sıkıntıyı tolere etme arasındaki ilişkide iyimserliğin aracı etkisi. Turkish Psychological Counseling and Guidance Journal, 9(53). Retrieved from https://dergipark.org.tr/en/pub/tpdrd/issue/46427/583284

Aydınlı, E. (2020). Post-Covid-19 global systems, old problems and new trends, epidemics and resilience of international systems. Ministry of Foreign Affairs Strategic Research Center (s. 35-39). Ankara: MATSA Publishing.

Baron, R. M. \& Kenny, D. A. (1986). The moderator-mediator variable distinction in social psychological research: Conceptual, strategic, and statistical considerations. Journal of Personality and Social Psychology, 51(6), 1173-1182.

Berkman, N. D. (2011). Low health literacy and health outcomes: An updated systematic review. Annals of Internal Medicine, 155, 97-107. Retrieved from https://doi.org/10.7326/0003-4819-155-2-20110719000005

Bertot, J. C., Jaeger, P. T. \& Hansen, D. (2012). The impact of polices on government social media usage: Issues, challenges, and recommendations. Government Information Quarterly, 29(1), 30-40. Retrieved from https://doi.org/10.1016/j.giq.2011.04.004

Bilgin, O. (2020). Development of Coronavirus (Covid-19) Awareness Scale: Validity and Reliability Study. Electronic Turkish Studies, 15(6), 237-239. doi: http://dx.doi.org/10.7827/TurkishStudies.44168 
Birru M. S., Monaco V. M., Charles L, ...\& Steinman RA. (2004). Internet usage by lowliteracy adults seeking health information: an observational analysis. Journal of Medical Internet Research, 6(3), 25-29 doi:10.2196/jmir.6.3.e25

Bo, H., Li, W., Yang, Y., Wang, Y., Zhang, Q., Cheung, T., Wu, X., \& Xiang, Y. (2020). Posttraumatic stress symptoms and attitude toward crisis mental health services among clinically stable patients with COVID19 in China. Psychological Medicine as part of the Cambridge Coronavirus Collection. https://doi.org/10.1017/S0033291720000999

Cyrus, S. H. H., Cornelia Y. I. C., \& Roger C. M. H., (2020). Mental health strategies to combat the psychological impact of COVID-19 beyond paranoia and panic, Journal of Academy Medicine, 49(3), 155160. Retrieved from http://www.anmm.org.mx/descargas/Ann-Acad-Med-Singapore.pdf

Chen, W., Zhang, D., Pan, Y., Hu, T., Liu, G., \& Luo, S. (2017). Perceived social support and self-esteem as mediators of the relationship between parental attachment and life satisfaction among Chinese adolescents. Personality and Individual Differences, 108, 98-102. doi:

https://doi.org/10.1016/j.paid.2016.12.009

Coşkun, S., \& Bebiş, H. (2015). Psychometric evaluation of a Turkısh version of the e-health literacy scale (e-heals) in adolescent. Journal of Gülhane Med., 57, 378-384. doi: 10.5455/gulhane.157832

Canöz, K. \& Öndoğan, A. G. (2015). "The role of transformatıonal leader ın crısıs management". Gumushane University E-Journal of Faculty of Communication, 3(1), s. 36-61. Retrieved from https://dergipark.org.tr/tr/download/article-file/83982

Chen, H., Xu, W., Paris, C., Reeson, A., \& Li, X. (2020). Social distance and SARS memory: impact on the public awareness of 2019 novel coronavirus (COVID-19) outbreak. medRxiv.

doi: https://doi.org/10.1101/2020.03.11.20033688

Connelly, L. M. (2016). Trustworthiness in qualitative research. Medsurg Nursing, 25(6), 435-437.

Retrieved from https://search.proquest.com/scholarly-journals/trustworthiness-qualitativeresearch/docview/1849700459/se-2?accountid=10527

Creswell, J. W. (2013). Research Design: Qualitative, Quantitative, And Mixed Methods Approaches. New York: Sage.

Çerçi, Ü. Ö., Canöz, N., \& Canöz, K. (2020). The use of social media as a means of information in the Covid-19 crissi period. Selcuk University Journal of Social Sciences Institute, 44, 184-198.

Çölgeçen, Y., \& Çölgeçen, H. (2020). Evaluation of Anxiety Levels Arising From Covid-19 Pandemic: The Case of Turkey. Turkish Studies, 15(4), 261-176. doi: http://dx.doi.org/10.7827/TurkishStudies.44399

De Hoog, N., Stroebe, W., \& de Wit, J. B. F. (2007). The impact of vulnerability to and severity of a health risk on processing and acceptance of fear-arousing communications: Ameta-analysis. Reviewof General 
Dugas, M. J., Freeston, M. H., \& Ladouceur, R. (1997). Intolerance of uncertainty and problem orientation in worry. Cognitive therapy and research, 21(6), 593-606. doi: https://doi.org/10.1023/A:1021890322153

Eicher, K., Wieser, S., \& Bruegger, U. (2009). The costs of limited health literacy: a systematic review. International Journal of Public Health, 54(5), 313-324. doi: 10.1007/s00038-009-0058-2

Enli Tuncay, F., Koyuncu, E., \& Özel, Ş., (2020). A review of protective and risk factors affecting psychosocial health of healthcare workers in pandemics, Ankara Med J, 2, 488-501. doi: 10.5505/amj.2020.02418

Erdoğdu, Y., Koçoğlu, F., \& Sevim, C. (2020). An investigation of the psychosocial and demographic determinants of anxiety and hopelessness during COVID-19 pandemic. Journal of Clin., 23, 1-14. doi: $10.5505 / \mathrm{kpd} .2020 .35403$

Gay, L. R., Mills, G., \& Airasian, P. W. (2009). Educational research: Competencies for analysis and interpretation. Upper Saddle Back, NJ: Merrill Prentice-Hall.

Gilham B. (2009). Case study research methods. (1 th ed). London: Continioum House Publishing.

Goto, E., Ishikawa, H., Okuhara, T., \& Kiuchi, T. (2019). Relationship Of Health Literacy With Utilization Of Health-Care Services in A General Japanese Population, Preventive Medicine Reports, 14, 1-5. Retrieved from https://doi.org/10.1016/j.pmedr.2019.01.015

Gray, N.J., Klein, J.D., Noyce, P.R., Sesselberg, T.S., Cantrill, J.A. (2005). The Internet: a window on adolescent health literacy. Journal of Adolescent Health 37(3), 243(1-7). doi:

10.1016/j.jadohealth.2004.08.023

González-Sanguino, C., Ausín, B., ÁngelCastellanos, M., Saiz, J., López-Gómez, A., Ugidos, C., \& Muñoz, M. (2020). Mental health consequences during the initial stage of the 2020 Coronavirus pandemic (COVID19) in Spain. Brain, Behavior, and Immunity 87;172-176 doi: 10.1016/j.bbi.2020.05.040

Haktanir, A., Seki, T., \& Dilmaç, B. (2020). Adaptation and evaluation of Turkish version of the fear of COVID-19 scale. Death Studies, 1-9. doi: 10.1080/07481187.2020.1773026

Hamermesh, D. S. (2020). Life satisfaction, loneliness and togetherness, with an application to Covid-19 lock-downs. Review of Economics of the Household, 18(4), 983-1000. Retrieved from https://doi.org/10.1007/s11150-020-09495-x

Howard, D., Gazmararian, J.A., \& Parker, R. (2005). The Impact of Low Health Literacy on the Medical Costs of Medicare Managed Care Enrollees. The American Journal of Medicine, 118(4), 371-377. doi: 10.1016/j.amjmed.2005.01.010. 
İlbasmış, Ç., Aksoy, A. T., Cihanyurdu, I.., Ünver, H., \& Rodopman, A. A. (2020). The Anxiety and Hope Levels of Adolescents for the Future in the COVID19 Outbreak. Turk Journal of Child Adolesc Ment Health, 99110.

Kaplan, H., Sevinç, K., \& İşbilen, N. (2020). Making sense of natural disasters and coping: a study on covid-19 outbreak in Turkey. Electronic Turkish Studies, 15(4), 579-600.

doi: $10.7827 /$ TurkishStudies.44477

Karataş, Z. (2020). Social Impacts of COVID-19 Pandemic, Change and Empowerment. Turkish Journal of Social Work Research, 4(1), 3-15. Retrieved from https://www.researchgate.net/publication/341878378

Kickbusch, I. S. (2001). Health literacy: addressing the health and education divide. Health promotion international, 16(3), 289-297. Retrieved from https://doi.org/10.1093/heapro/16.3.289

Li, P., Fu, J. B., Li, K. F., Liu, J. N., Wang, H. L., ... \& Yan, J. B. (2020). Transmission of COVID-19 in the terminal stages of the incubation period: A familial cluster. International Journal of Infectious Diseases, 96, 452-453. https://doi.org/10.1016/j.ijid.2020.03.027

Longstaff, P. H. \& Sung-un, Y. (2008). “Communication management and trust: their role in building resilience to "surprises" such as natural disasters, pandemic flu, and terrorism". Ecology and Society 13(1): 3. Retrieved from http://www.ecologyandsociety.org/vol13/iss1/art3

Lu, J., Gu, J., Li, K., Xu, C., Su, W., ... \& Yang, Z. (2020). COVID-19 outbreak associated with air conditioning in restaurant, Guangzhou, China, Emerging infectious diseases, 26(7), 1628.

doi:10.3201/eid2607.200764.

Miles, M. B. \& Huberman, A. M. (2016). Qualitative Data Analysis. Sadegül Akbaba Altun ve Ali Ersoy (Ed.). Ankara: Pegem Publishing.

Ministry of Health (2020; March 25). The number of the current chorus in Turkey. Retrieved date: January 24, 2021. Retrieved February, 15 2021, from https://covid19.saglik.gov.tr/

Modi, P. D, Nair, G., Uppe, A., Modi, J., Tuppekar, B., ... \& Langade, D. (2020). COVID-19 Awareness among healthcare students and professionals in Mumbai Metropolitan Region: A questionnaire-based survey. Cureus 12(4), e7514. doi:10.7759/cureus.7514.

Moghanibashi-Mansourieh, A. (2020). Assessing the anxiety level of Iranian general population during COVID-19 outbreak. Asian journal of psychiatry, 102076. https://doi.org/10.1016/j.ajp.2020.102076

Okyay, P., \& Abacıgil, F. (2016). Turkısh adaptatıon of the european health literacy scale (ASOY-TR). Retrieved from https://sbu.saglik.gov.tr/Ekutuphane/Yayin/530

Oral T, \& Gunlu A. (2020). The impact of the Covid-19 pandemic on education and psychological health (1 th ed). In: Şahin, H. (ed), Educational Sciences-Theory, Current Researches and New Trends, IVPE Press, 
Centinje/Montenegro, pp 87-103.

Oral, T. \& Gunlu, A. (2021). Adaptation of the Social Distancing Scale in the covid-19 era: Its association with depression, anxiety, stress and resilience in Turkey. International Journal of Mental Health and Addiction, Advance Publication, 1-18.

Oran, N. T., \& Şenuzun, F. (2008). A loop to be broken in a society: HIV/AIDS stigma and coping strategies. International Journal of Human Sciences, 5(1), 1-16. Retrieved from https://www.jhumansciences.com/ojs/index.php/IJHS/article/view/340

Özdin, S., \& Bayrak Özdin, Ş. (2020). Levels and predictors of anxiety, depression and health anxiety during COVID-19 pandemic in Turkish society: The importance of gender. International Journal of Social Psychiatry, 0020764020927051.

Özer, Ö., Şantaş, B., Budak, F. (2012). A study of health web sıtes' usage level: a case applıcatıon. gumushane University E-Journal of Faculty of Communication, 4(1), 128-140. Retrieved from https://dergipark.org.tr/tr/pub/e-gifder/issue/7471/98384

Qazi, A., Qazi, J., Naseer, K., Zaeshan, M., Hardaker, G., Maitama, J. Z. \& Haruna, K. (2020). Analyzing situational awareness through public opinion to predict adoption of social distancing amid pandemic COVID-19. Journal of Medical Virology, 92(7), 849-855. doi: https://doi.org/10.1002/jmv.25840

Paakkari L, \& Okan O. (2020). COVID-19: Health literacy is an underestimated problem. The Lancet Public Health. 5(5):e249-e50 doi: 10.1016/S2468-2667(20)30086-4

Parvanta, C. F. (2011). Introduction to Public Health Communication and Informatics. (Edt. C.F. Parvanta). In Essentials of Public Health Communication. p.1-19. USA: Jones and Bartlett.

Polizzi, C., Lynn, S.J., \& Perry, A., (2020). Stress and Coping in the Time of COVID-19: Pathways to Resilience and Recovery, Clinical Neuropsychiatry, 17(2), 59-62. doi:

https://doi.org/10.36131/CN20200204

Rajkumar, R. P., (2020). COVID-19 and Mental Health: A Review of the Existing Literature, Asian Journal of Psychiatry, 52, 102066. doi: https://doi.org/10.1016/j.ajp.2020.102066

Ramaci, T., Barattucci, M., Ledda, C., \& Rapisarda, V. (2020). Social Stigma during COVID-19 and its impact on HCWs outcomes. Sustainability, 12(9), 3834. doi: https://doi.org/10.3390/su12093834

Ruiter, R.A.C., Abraham, C, \& Kok, G. (2001). Scary warnings and rational precautions: A review of the psychology of fear appeals. Psychology \& Health, 16, 613-630. Retrieved from https://doi.org/10.1080/08870440108405863

Sezgin, D. (2013). Understanding Health Literacy. Journal of Communication, 73-92. Retrieved from http://iletisimdergisi.gsu.edu.tr/tr/download/article-file/82916 
Shenton, A. K. (2004). Strategies For Ensuring Trustworthiness in Qualitative Research Projects. Education for IIInformation, 22(2), 63-75. doi: 10.3233/EFI-2004-22201

Skinner, H., Biscope, S., Poland, B., \& Goldberg, E. (2003). How adolescents use technology for health information: implications for health professionals from focus group studies. Journal of medical Internet research, 5(4), e32. doi: 10.2196/jmir.5.4.e32

Snyder, C. R., Harris, C., Anderson, J. R., Holleran, S. A., Irving, L. M., ... \& Harney, P. (1991). The will and ways: Development and validation of an individual-differences measure of hope. Journal of Personality and Social Psychology, 60 (4), 570- 585. Retrieved from https://doi.org/10.1037/0022-3514.60.4.570

Sorensen, K., Van den Broucke, S., Fullam, J., Doyle, G., Pelikan, J., ... \& Brand, H. (2012). (HLSEU) Consortium Health Literacy Project European. Health literacy and publichealth: a systematic review and integration of definitions and models. BMC PublicHealth, 25, 12:80. Retrieved from https://doi.org/10.1186/1471-2458-12-80

Spadaro, R. (2003). European Opinion Research Group (EORG) Eurobarometer 58.0. European Union citizens and sources of informatio $n$ about health, p. 2-16.

Sun, Y., Koh, V., Marimuthu, K., Ng, O. T., Young, B., Vasoo, S., ... \& Leo, Y. S. (2020). Epidemiological and clinical predictors of COVID-19. Clinical Infectious Diseases, 71(15), 786-792. doi: 10.1093/cid/ciaa322.

Tamer Gencer, Z. (2017). Analysis of validity and reliability of Norman and Skinner's e-Health scale literacy for cultural adaptation. Istanbul University Journal of Communication Sciences, 52, 131-145. doi: 10.17064/iuifd.333165

Turkish Medical Association [TMA]. (2020). Covid-19 pandemic two-month evaluation report. Retrieved date: May 14, 2020. Retrieved from: https://www.ttb.org.tr/userfiles/files/covid19-rapor.pdf

Tarhan, S., \& Bacanlı, H. (2015). Adaptation of Dispositional Hope Scale into Turkish: Validity and reliability study. The Journal of Happiness \& Well-Being, 3(1), 1-14.

Tirkkonen, P., \& Luoma-aho, V. (2011). Online authority communication during an epidemic: A Finnish example. Public Relations Review, 37(2), 172-174. doi:10.1016/j.pubrev.2011.01.004

Turan, A., \& Çelikyay, H. H. (2020). Fight Against COVID-19 in Turkey: Policies and Actors. International Journal of Management Academy, 3(1), 1-25.

Unutulmaz, O. (2020). Covid-19 pandemic, immigration. In Global System After Covid-19: Old Problems, New Trends (s. 135-140). Ankara: MATSA Publishing.

Xiao, H., Zhang, Y., Kong, D., Li, S., \& Yang, N. (2020). Social Capital and Sleep Quality in Individuals Who Self-Isolated for 14 Days During the Coronavirus Disease 2019 (COVID-19) Outbreak in January 2020 in 
China. International Medical Journal of Experimental and Clinical Research, 26, e923921- e923921-1e923921-8). https://doi.org/10.12659/MSM.923921

Wang, C., Pan, R., Wan, X., Tan, Y., Xu, L., Ho, C. S., \& Ho, R. C. (2020). Immediate Psychological Responses and Associated Factors During The Initial Stage of The 2019 Coronavirus Disease (COVID-19) Epidemic Among The General Population in China. International Journal of Environmental Research and Public Health, 17(5), 1729. https://doi.org/10.3390/ijerph17051729

World Health Organization [WHO], (2021, March 15). The current number of corona in the World. Retrieved from:. Retrieved January 24, 2021 from https://covid19.who.int/

Van Bavel, J. J., Baicker, K., Boggio, P. S., Capraro, V., Cichocka, A., Cikara, M., ... \& Drury, J. (2020). Using social and behavioural science to support COVID-19 pandemic response. Nature Human Behaviour, 460471. Retrieved from https://doi.org/10.1038/s41562-020-0884-z

Yalçınkaya, Hikmet (2020, March 12), "How was the 'Scientific Committee' that Brings Together Experts Founded?", E-News, Retrieved January 12, 2021, from https://www.gzt.com/jurnalist/uzmanlari-biraraya-getiren-bilim-kurulu-nasil-kuruldu-3531656.

Yang, H., \& Ma, J. (2020). How an Epidemic Outbreak Impacts Happiness: Factors that Worsen (vs. Protect) Emotional Well-being during the Coronavirus Pandemic. Psychiatry Research, 289, 113045. doi: 10.1016/j.psychres.2020.113045

Yılmaz, M., \& Tiraki, Z. (2016). What is the Health Literacy? How Assessment?. Dokuz Eylul University EJournal of Nursing Faculty, 9(4), 142-147. Retrieved from

https://dergipark.org.tr/tr/pub/deuhfed/issue/46793/586772

Yıldırım, A. \& Şimşek, H.(2011). Qualitative research methods in the social sciences. Ankara: Seckin Publishing.

Zhou, S. J., Zhang, L. G., Wang, L. L., Guo, Z. C., Wang, J. Q., Chen, J. C., ... \& Chen, J. X. (2020). Prevalence and socio-demographic correlates of psychological health problems in Chinese adolescents during the outbreak of COVID-19. European Child \& Adolescent Psychiatry, 1-10. doi: 10.1007/s00787-020-01541-4

\section{Figures}




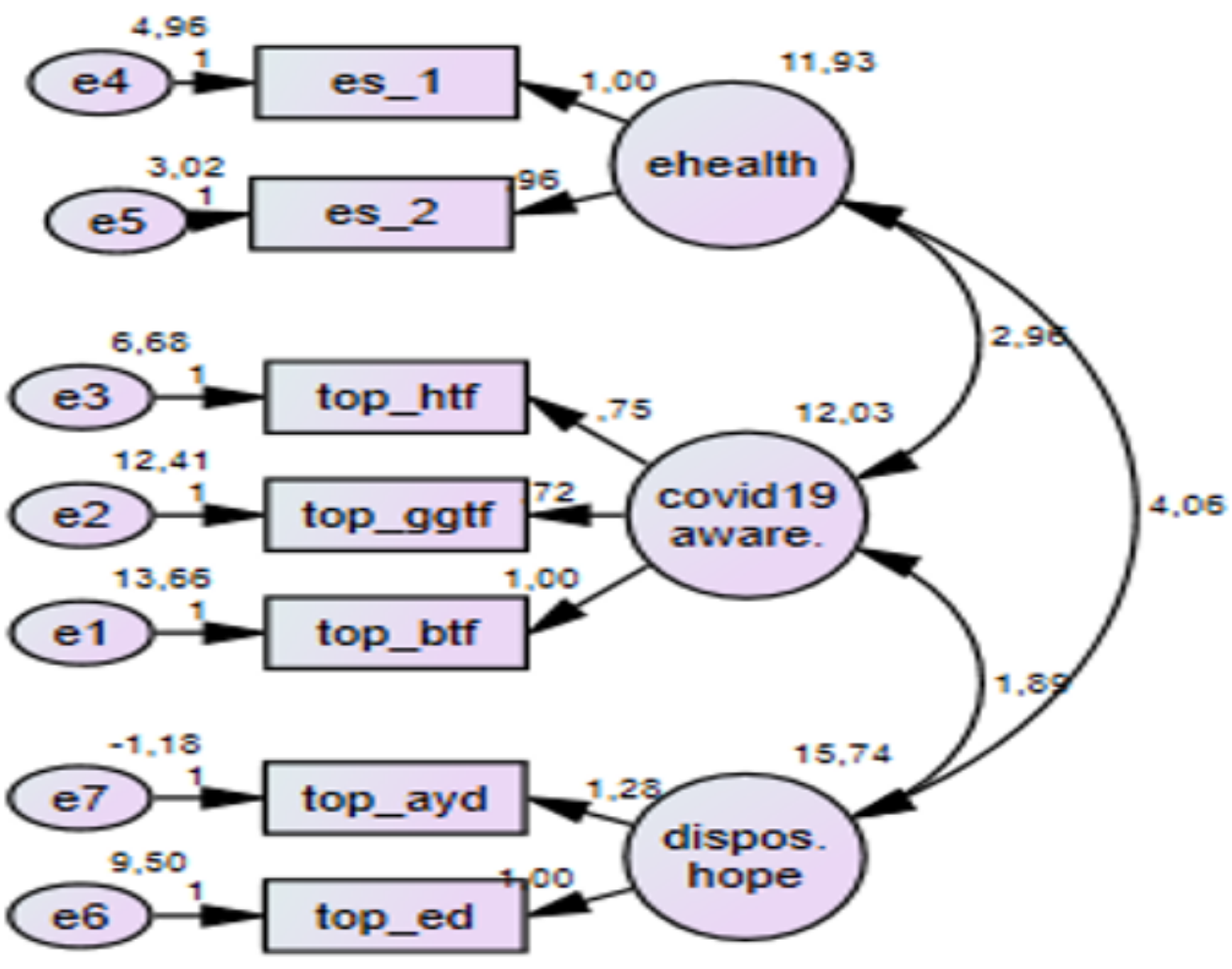

Figure 1

Analysis results regarding the measurement model

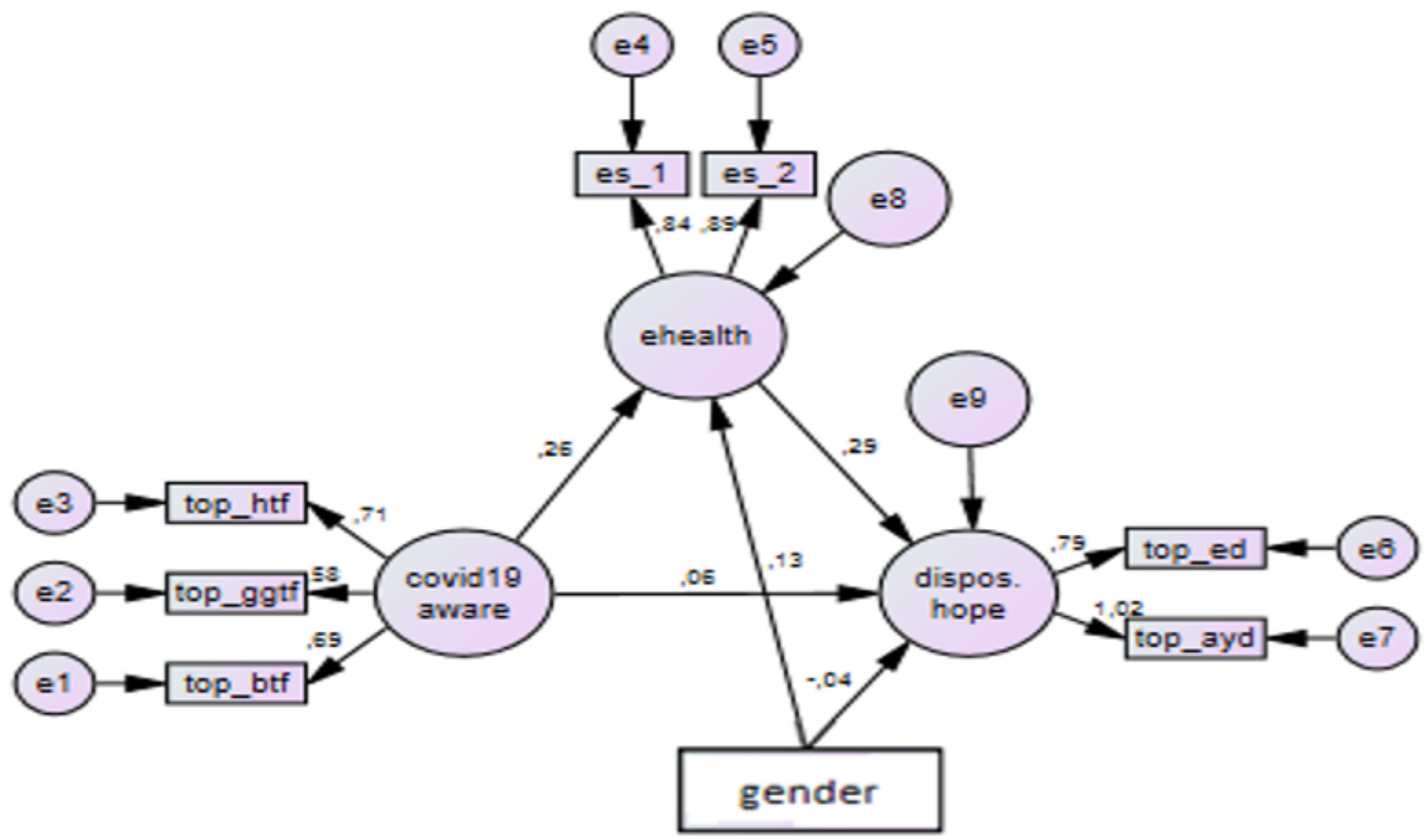


Figure 2

Testing the mediating role of e-health literacy in the relationship between coronavirus awareness and dispositional hope (covid19 aware = coronavirus awareness, ehealth $=$ e-health literacy, dispos. hope= dispositional hope)

a)

Covid-19
Awareness

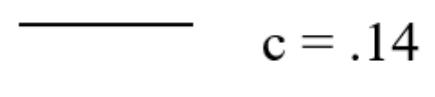

b)

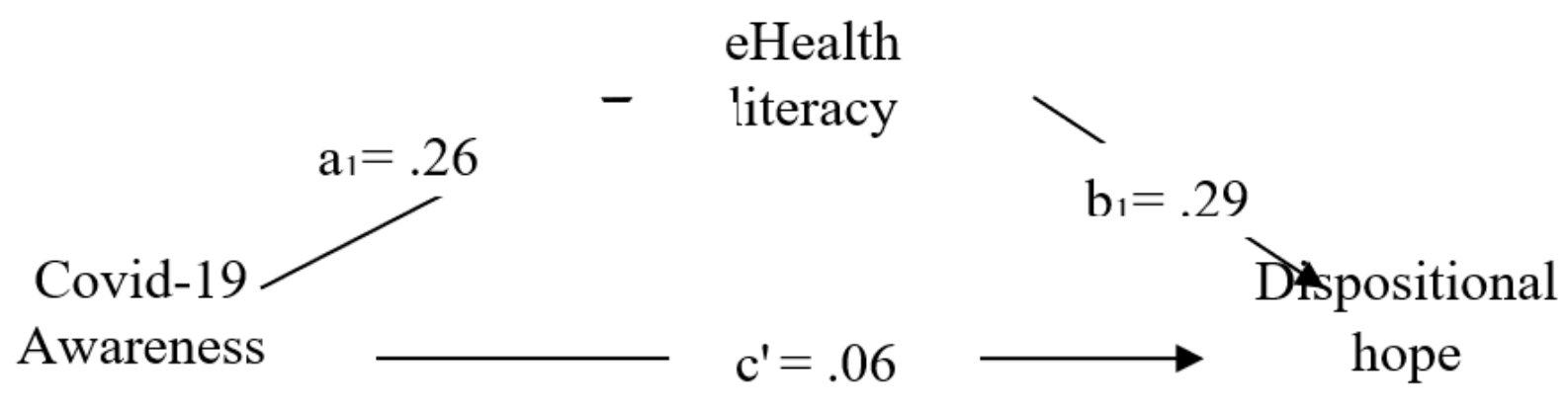

Figure 3

Indirect effects of e-health literacy in the relationship between coronavirus awareness and dispositional hope (Fig.-b). 